\title{
Starch addition in renneted milk gels: Partitioning between curd and whey and effect on curd syneresis and gel microstructure ${ }^{1}$
}

\author{
K. M. Brown, W. R. McManus, and D. J. McMahon ${ }^{2}$ \\ Western Dairy Center, Department of Nutrition, Dietetics, and Food Sciences, Utah State University, Logan 84322-8700
}

\begin{abstract}
Milk gels were made by renneting and acidifying skim milk containing 5 different starches, and then compressed by centrifugation to express whey and simulate curd syneresis during the manufacture of low-fat cheese. A series of 17 starches were examined, with 5 starches being selected for in-depth analysis: a modified waxy corn starch (WC), a waxy rice starch (WR), an instant tapioca starch (IT), a modified tapioca starch (MT), and dextrin (DX). Milks containing WC, WR, and $\mathrm{DX}$ were given a $72^{\circ} \mathrm{C}$ heat treatment, whereas those containing IT and MT had a 30-min treatment at $66^{\circ} \mathrm{C}$ that matched their optimum gelatinization treatments. Curd yields were calculated by weight, estimated starch content in whey was measured gravimetrically by alcohol precipitation, and starch retention in curd was calculated. Curd yields were $13.1 \%$ for the control milk (no added starch) and 18.4, 20.7, 21.5, 23.5, and $13.2 \%$ for the gels containing starches WC, WR, IT, MT, and DX, respectively. Estimated starch retentions in the curd were, respectively, $71,90,90,21$, and $1 \%$. Laser scanning confocal microscopy was used to determine the location of the starches in the curd and their interaction with the protein matrix. Waxy corn, WR, and IT starches have potential to improve texture of low-fat cheese because they had high retention in the curd and they generated interruptions in the protein matrix network that may have helped limit extensive protein-protein interactions. Modified tapioca starch interfered with formation of the protein structure of the curd and produced a soft noncohesive gel, even though most $(79 \%)$ of the MT starch was lost in the whey. Few distinct starch particles were present in the MT curd network. Dextrin was not retained in the curd and did
\end{abstract}

\footnotetext{
Received November 25, 2011.

Accepted August 14, 2012.

${ }^{1}$ The use of trade names in this publication does not imply endorsement by Utah State University (Logan) of the products named or criticism of similar ones not mentioned. This research was supported by the Utah Agricultural Experiment Station, Utah State University, and approved as journal paper No. 8300.

${ }^{2}$ Corresponding author: donald.mcmahon@usu.edu
}

not disrupt the protein network, making it unsuitable for use in low-fat cheese.

Key words: starch, low-fat, cheese, microstructure

\section{INTRODUCTION}

Development of low-fat foods is often difficult because removing fat from many food systems results in foods with poor sensorial and functional qualities (Johnson et al., 2009). Low-fat natural cheese is one such food where fat reduction gives the cheese a hard, rubbery texture (Drake and Swanson, 1995). Fat has the important role in cheese of imparting discontinuity to the protein matrix (Rogers et al., 2010), so that when fat is removed, the cheese is composed of a homogenous, dense protein network (Paulson et al., 1998). Starch and other hydrocolloids have been suggested as possible remedies for improving the texture of low-fat cheese, and have been used in some commercial low-fat cheeses.

Starches embody a diverse array of functional attributes that, through modifications such as cross-linking, acid hydrolysis, or substitution, can be manipulated to serve almost any function within a food matrix (BeMiller and Whistler, 1996). Use of starch is common in dairy products such as ice cream and yogurt, and have also been used in Mozzarella and process cheeses (Cody et al., 2007; Merrill and Anderson, 2007; Trivedi et al., 2008). Starch inclusion in ice cream provides enhanced creaminess, improves mouthfeel, and improves freezethaw stability (Stanley et al., 1996; Cody et al., 2007). In yogurt, it enhances mouthfeel and helps prevent syneresis (Sandoval-Castilla et al., 2004). In cheeses, starch has been used for its water-binding properties and to modify baking properties.

Besides starch, other polysaccharides such as gums, as well as protein-based fat mimetics, surfactants, and emulsions have been investigated in low-fat cheeses for improving texture (Mistry, 2001). This includes $\beta$-glucan (Konuklar et al., 2004; Vithanage et al., 2008), lecithin (Drake et al., 1996; Sipahioglu et al., 1999), gum tragacanth (Rahimi et al., 2007), carrageenan (Kavas et al., 2004; Totosaus and Guemes-Vera, 2008), pectin (Liu et al., 2008), protein and carbohydrate microparticles (McMahon et al., 1996), emulsions (Lobato-Calleros et 
al., 2008), and exopolysaccharide-producing bacteria (Perry et al., 1997). Under US regulations for low-fat foods [21 Code of Federal Regulations (CFR) 130.10], such ingredients may be added, provided they have a functional property, even though they are not permitted in the standardized full-fat cheese (FDA, 2012).

Sipahioglu et al. (1999) used a modified tapioca starch and lecithin to increase moisture content and soften reduced-fat Feta cheese. Adding a modified potato starch has been used for making low-fat white pickled cheese (Kavas et al., 2004) with no difference in moisture content, resulting in a cheese that was harder and chewier than low-fat cheese made without added starch. Starch will compete with the protein in cheese for water, so this may have increased the cheese hardness; however, Kavas et al. (2004) did not determine losses of the starch into the whey (which can be quite high) or starch content of the cheese.

Bhaskaracharya and Shah (2001) looked at inclusion of 2 types of maltodextrins and a modified (particulated) potato starch in low-fat Mozzarella cheese. They observed that potato starch increased hardness of the cheese and decreased the moisture content. Potato starch particles were distributed in serum pockets as well as in the protein matrix of the cheese. These particles apparently swelled during storage and removed moisture from the surrounding proteins. The maltodextrin-based fat replacers had amorphous gellike structures that improved texture characteristics of the cheese and increased openness. Bhaskaracharya and Shah (2001) attributed the differing properties of the cheeses made with the different starches to the starches' particle sizes, degrees of microparticulation, and to their interactions with casein. In Cheddar cheese made using a blend of modified corn starch and microparticulated microcrystalline cellulose, Aryana and Haque (2001) observed an 11\% increase in cheese moisture and a softening of the cheese. However, they did not observe any increase of discontinuities within the protein matrix of the cheese. McMahon et al. (1996) reported a $4 \%$ increase in moisture of low-fat Mozzarella cheese when a similar polysaccharide fat replacer was used, and observed increased openness and formation of large serum channels in the cheese microstructure.

The manufacture of rennet-set cheeses involves separating the curd from whey, with the whey being converted into other products so absence of starch in the whey (i.e., starch retention in the curd) is an important factor regarding its potential for use in making low-fat cheese. Our goal was to compare the effect of starches with a diverse range of hydration properties on curd syneresis. We used a model system of rennet-induced partially acidified skim milk gels that were then centrifuged to accelerate whey expulsion, and quantified partitioning of starch between curd and whey and the effect of starch on milk gel microstructure using laser scanning confocal microscopy (LSCM). In doing so, a new method for visualizing starch in the presence of proteins in a food system was developed (McManus et al., 2009).

\section{MATERIALS AND METHODS}

\section{Materials}

Pasteurized $\left(73^{\circ} \mathrm{C}\right.$ for $\left.15 \mathrm{~s}\right)$ skim milk was obtained from the Gary H. Richardson Dairy Products Laboratory (Utah State University, Logan) and stored at $4^{\circ} \mathrm{C}$. Starches (Table 1) were donated by National Starch LLC (Bridgewater, NJ; notebook 1180346). Glucono$\delta$-lactone was from Purac America Inc. (Blair, NE), chymosin rennet [Maxiren DS; $\sim 650$ international clotting units $/ \mathrm{mL}$ ] was from DSM Food Specialties USA Inc. (Parsippany, NJ). Celite, periodic acid, acriflavine $\mathrm{HCl}$, and Rhodamine B were from Sigma Aldrich (St. Louis, MO). Osmium tetroxide was from Ted Pella Inc. (Redding, CA). All other chemicals were reagent grade.

\section{Starch Swelling}

Swelling properties of the 17 starches (Table 1) were measured in duplicate based upon Konik-Rose et al. (2001) to determine the amount of water each starch holds when subjected to different heat treatments. In 50-mL conical centrifuge tubes, $0.40 \pm 0.003 \mathrm{~g}$ of starch was added to $40 \mathrm{~mL}$ of distilled deionized water $\left(\sim 22^{\circ} \mathrm{C}\right)$ and heated with agitation to 60,66 , or $72^{\circ} \mathrm{C}$. Solutions heated to 60 or $66^{\circ} \mathrm{C}$ were held for $30 \mathrm{~min}$ at their respective temperatures, whereas those heated to $72^{\circ} \mathrm{C}$ were cooled immediately. Heat treatments examined were based on manufacturer recommendations for ideal starch gelatinization. The solutions were cooled to room temperature and centrifuged at 2,000 $\times$ $g$ for $20 \mathrm{~min}$. Following centrifugation, the pellet and supernatant were weighed and water-holding capacity calculated. The moisture content of each starch powder was determined using a vacuum oven at $66^{\circ} \mathrm{C}$ for $18 \mathrm{~h}$.

\section{Milk Gels}

Preliminary Study. The 17 starches (Table 1) were dispersed in cold milk at 5 and $10 \mathrm{~g} / \mathrm{L}$. Six 200-mL batches of each starch-in-milk solution (plus a milkonly control) were prepared in $250-\mathrm{mL}$ polycarbonate Nalgene centrifuge bottles (Thermo Fischer Scientific, Rochester, NY) and then given 3 different heat treatments (in duplicate) based upon observations on optimum starch swelling: heating to $63^{\circ} \mathrm{C}$ and then imme- 
Table 1. Starch description and properties

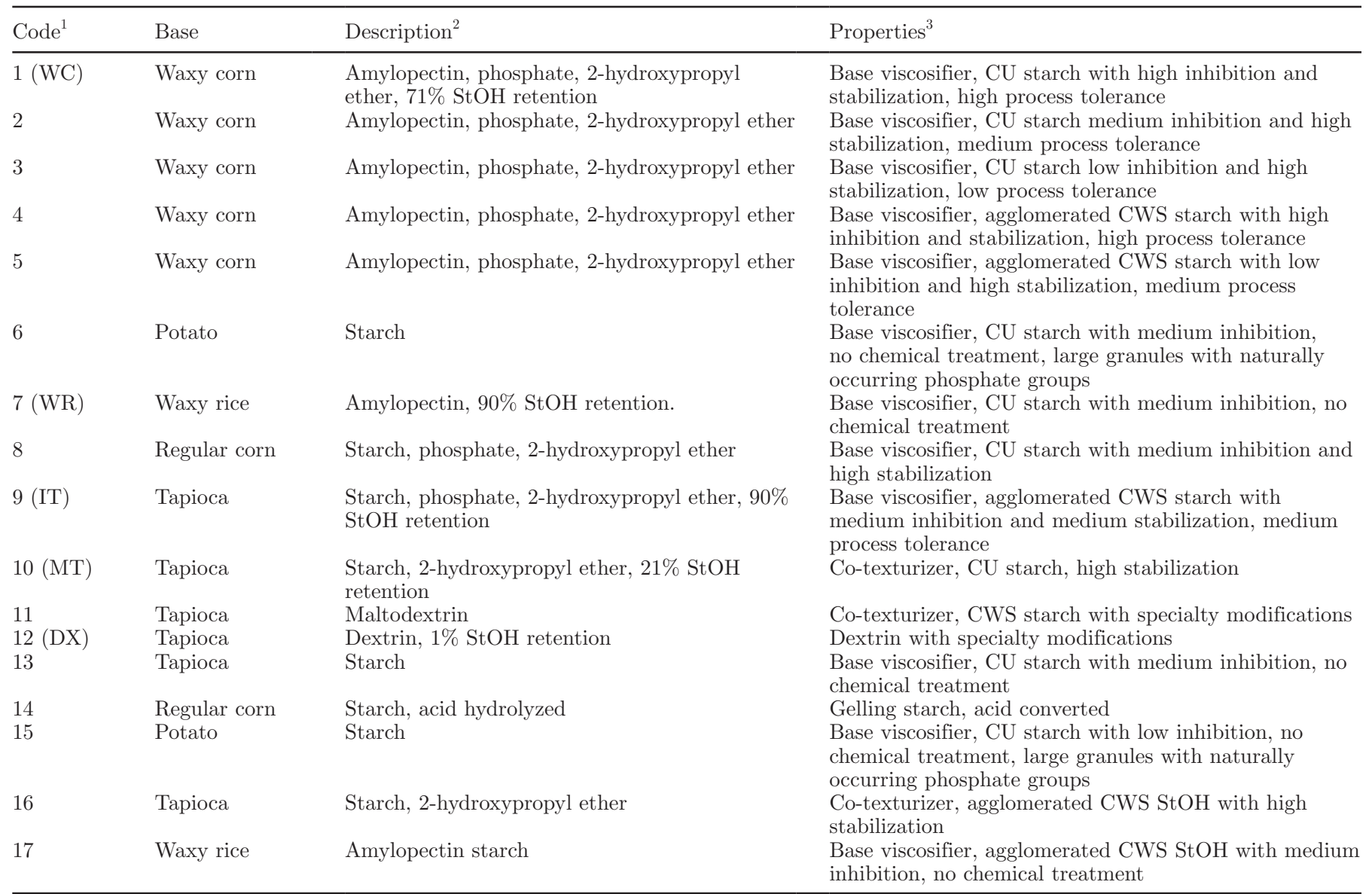

${ }^{1}$ Starches 1 to 17 used in the initial study and waxy corn (WC), waxy rice (WR), instant tapioca (IT), modified tapioca (MT), and dextrin (DX) starches used in the second detailed study.

${ }^{2} \mathrm{StOH}=$ starch hydroxyl content.

${ }^{3} \mathrm{CU}=$ cook-up; CWS $=$ cold water swelling.

diately cooled, heating to $72^{\circ} \mathrm{C}$ and then immediately cooled, or heating to $63^{\circ} \mathrm{C}$, held for $30 \mathrm{~min}$, and then cooled.

Four grams of glucono- $\delta$-lactone and $400 \mu \mathrm{L}$ of $1: 10$ diluted chymosin rennet ( 130 international clotting units $/ \mathrm{kg}$ of milk) were added to each mixture after cooling to $35^{\circ} \mathrm{C}$ and then incubated for $30 \mathrm{~min}$ to allow coagulum formation. The resultant gel was then cut with a spatula vertically with 3 cuts in each of 2 perpendicular directions. Bottles containing the curd and whey were centrifuged at $250 \times g$ for $30 \mathrm{~min}$ at $25^{\circ} \mathrm{C}$; by this time, the $\mathrm{pH}$ of the mixture dropped to approximately $\mathrm{pH}$ 5.1. The whey was decanted immediately after centrifugation and again after $30 \mathrm{~min}$, and its volume measured using a graduated cylinder. Curd yield was calculated on a volume basis and expressed as a percentage.

Second Study. Five starches from Table 1 were selected that were representative of the various per- formance attributes of starch when incorporated into a milk gel: modified waxy corn (WC) starch, waxy rice (WR) starch, instant tapioca (IT) starch, modified tapioca (MT) starch, and dextrin (DX) starch. Milk-starch mixtures (with starch concentration of 5 $\mathrm{g} / \mathrm{L}$ ) were prepared and those containing WC, WR, or DX starch were heated to $72^{\circ} \mathrm{C}$ and then immediately cooled. Milk-starch mixtures containing IT and MT starch were heated to $66^{\circ} \mathrm{C}$ and held for 30 min before cooling. Control samples without starch were heated to both temperatures. The milk solutions were converted into gels as described above with slight modification in that centrifugation was at $500 \times g$ for $15 \mathrm{~min}$, followed by $1,000 \times g$ for $15 \mathrm{~min}$.

After centrifuging, gels were evaluated visually for curd appearance, settling of starch, clean separation of whey from curd, sliminess, viscosity, and similarity of whey released from milk gels containing starch to that from controls. Whey was decanted immediately after 
centrifugation, and whey and curd weighed. Curd and whey yields were calculated and expressed as a percentage of original weight of the milk-starch mixture. A portion of the whey was used to measure the moisture content (in triplicate) and another portion was frozen and retained for starch analysis. The curd was retained for microstructural analysis.

\section{Starch Loss in Whey}

Starch lost in whey was quantified using a modified version of the method for measuring total dietary fiber (AOAC, 1990). Four frozen whey samples from each starch-containing curd (and from the controls) were thawed. Approximately $12 \mathrm{~g}$ of each whey (in duplicate) was measured into beakers, $50 \mathrm{~mL}$ of $0.08 M$ phosphate buffer ( $\mathrm{pH}$ 6.0) was added to each sample, and the $\mathrm{pH}$ was adjusted to between 4.0 and 4.6 with $0.275 \mathrm{M} \mathrm{HCl}$. Then, $280 \mathrm{~mL}$ of $95 \%$ ethanol, warmed to $60^{\circ} \mathrm{C}$, was added to each sample and the precipitate allowed to form for $60 \mathrm{~min}$. Coarse-fritted, 50-mL glass crucibles (Cole Parmer, Vernon Hills, IL) containing $0.5 \mathrm{~g}$ of acid-washed Celite were dried for $18 \mathrm{~h}$ in a vacuum oven at $66^{\circ} \mathrm{C}$ and weighed before use; before filtration, the bed of Celite was evenly redistributed using $78 \%$ ethanol. After 60 min, each sample was filtered through the crucibles and washed with three $20-\mathrm{mL}$ portions of $78 \%$ ethanol, two $10-\mathrm{mL}$ portions of $95 \%$ ethanol, and two 10-mL portions of acetone. Following filtration, crucibles containing residue were dried for 18 $\mathrm{h}$ in a vacuum oven at $66^{\circ} \mathrm{C}$ then weighed.

Analyzing starch in water solutions of known concentration was used to determine recovery of starch after ethanol precipitation. Solutions of each starch were made and given heat treatments identical to the milk used to make the model cheeses. A portion of each solution containing approximately $0.04 \mathrm{~g}$ of starch measured on an analytical balance was analyzed as described above. Weights of residues were compared with the known amount of starch in each solution.

\section{Microstructure}

Curd samples were prepared for microstructural analysis using LSCM as described by McManus et al. (2009). Curd was cut to $1 \times 1 \times 1$-cm cubes and protein was fixed with $1 \%$ (wt/vol) osmium tetroxide prepared in whey solution obtained from centrifuging the milk gel (to avoid changes in ionic environment during fixation). Samples in fixative were microwaved (model 3470; Ted Pella Inc., Redding, CA) at high power under vacuum for 4 cycles of 2 min on then 2 min off while the sample was maintained at $31^{\circ} \mathrm{C}$ and then stored for $18 \mathrm{~h}$ at $4^{\circ} \mathrm{C}$. Prior to imaging, samples were cut into 1-mm thick slices and placed for $20 \mathrm{~min}$ in $0.5 \%$ (wt/vol) aqueous periodic acid solution to oxidize the starch, and washed with several exchanges of deionized distilled water. Next, samples were immersed in 1\% (wt/vol) aqueous acriflavine $\mathrm{HCl}$ to attach the fluorophore to aldehyde groups formed by oxidization of starch, using the same microwave procedure. Samples were washed until little fluorophore was visible in the wash water, and were next immersed in $0.01 \%$ (wt/vol) aqueous rhodamine $\mathrm{B}$ to stain protein and then again microwaved. Samples were again washed and mounted on a glass slide with glycerol/gelatin (Horobin and Kiernan, 2002) and covered with a coverslip.

To confirm that imaging of starch was occurring, $50-\mathrm{mL}$ solutions of $5 \mathrm{~g}$ of starch/L of water were gelatinized and treated $\left(\right.$ at $22^{\circ} \mathrm{C}$ ) with $0.1 \mathrm{~g}$ of periodic acid and allowed to oxidize for $20 \mathrm{~min}$. An additional $20 \mathrm{~mL}$ of water was added to each solution and then tubes were centrifuged for $5 \mathrm{~min}$ at $3,000 \times g$. The supernatant was decanted and more water was added to bring the volumes back to $40 \mathrm{~mL}$. Tubes were shaken to wash the pelleted material and then centrifuged and decanted again. Five milliliters of $0.3 \%$ (wt/vol) aqueous acriflavine was added to each tube. Solutions were allowed to stain for $10 \mathrm{~min}$ and then were extensively washed, following the same protocol for washing out the periodic acid. Once no residual dye was apparent in supernatants, the gelatinized starch pellets were smeared on glass slides. A drop of water was placed on top of each smear, which then was covered with a glass coverslip as described above.

Samples were imaged on a confocal microscope (MRC 23; Bio-Rad Laboratories Inc., Hercules, CA) with a $\mathrm{Kr} / \mathrm{Ar}$ laser exciting the acriflavine at $488 \mathrm{~nm}$ and the rhodamine B at $568 \mathrm{~nm}$. Emissions were from 488 to $650 \mathrm{~nm}$ and 550 to $750 \mathrm{~nm}$, respectively, and exclusion filters of 512 to $532 \mathrm{~nm}$ and above $585 \mathrm{~nm}$ were used to capture the fluorescent signals of acriflavine bound to oxidized starch and rhodamine B bound to protein, respectively. Images were false colored, with protein as red-orange and starch as yellow-green.

\section{Statistical Analysis}

Moisture contents were measured in triplicate. Curd and whey yields were calculated based on 4 samples per curd type. Alcohol precipitation was done in duplicate for 4 whey samples from each type of curd. Differences in alcohol-insoluble residue for all curd types were determined with SAS 9.0 (SAS Institute Inc., Cary, NC) using PROC GLM with a one-way factorial design, Tukey-Kramer adjustment for mean comparison, and significance declared at $\alpha=0.05$. Recovery factors were determined using 5 samples per starch. Confocal imag- 
ing was done on at least 2 subsamples of 3 curd samples for each type of curd with images from multiple fields of each sample recorded.

\section{RESULTS}

\section{Starch Swelling}

Extent of starch swelling and the influence of heat treatment used for gelatinization are shown in Figure 1. Only starches 15 and 17 exhibited any difference in swelling based on type of heat treatment. The starches were then grouped according to water-holding capacity by pooling over all heat treatments. Starches that held $<1.0 \mathrm{~g} / \mathrm{g}$ of water were classified as nonswelling (starches 11 and 12), 1.0 to $5.0 \mathrm{~g} / \mathrm{g}$ as low swelling (starch 14), 5.1 to $15.0 \mathrm{~g} / \mathrm{g}$ as medium swelling (starches 1, 2, 7, 8, 9, 13, and 17), 15.1 to $24.0 \mathrm{~g} / \mathrm{g}$ as high swelling (starches $3,4,5,6$, and 10), and $>24.0$ $\mathrm{g} / \mathrm{g}$ as very high swelling (starch 15). Starches 10 and 16 separated poorly during centrifugation and so water retention values (see Figure 1) for these starches could only be estimated or were not obtained.

\section{Preliminary Curd Studies}

Curd yield from the control milks ranged from 11.8 to $14.3 \%$, with the higher yield occurring in milk heated to $72^{\circ} \mathrm{C}$ and was indicative of the presence of denatured $\beta$-LG being retained in the milk gel, hindering contraction of the casein network and producing a higher-moisture gel. The yield from all the control milks was higher than the 9 to $10 \%$ yield observed for Cheddar cheese, but less curd compression occurred in the model system than in normal cheesemaking. The model system leaves out process steps applied to dry curd, such as stirring, salting, and pressing, which further concentrate the protein matrix and promote whey drainage from the curd. Adding starches to milk produced curd yields ranging from 11 to $28 \%$ when $5 \mathrm{~g}$ of starch/L was added (Figure 2) and from 11 to $50 \%$ when $10 \mathrm{~g}$ of starch/L was added (data not shown), depending on the type of starch and heat treatment. Starches 11 and 12 (maltodextrin and dextrin starches) did not significantly increase curd yield. Starches 13 and 14 (tapioca starch and the traditional gelling, acid-converted starch) only increased curd yield when milk had been heated to $72^{\circ} \mathrm{C}$. At the 5 -g/L level, this increase could be explained by an increase in whey protein denaturation at the higher temperature (as occurs with the control milks), whereas at the $10-\mathrm{g} / \mathrm{L}$ level, the yields for starches 13 and 14 increased to $20 \%$ compared with 11 to $12 \%$ when heated at the lower temperatures. Starches 1 to 10, 15, 16, and 17 significantly increased curd yield, with the effect being more pronounced at higher concentration and heat treatment.

Higher heat treatment generally increases swelling of starch granules and incorporation of hydrated starch into the paracasein network that forms as the renneted milk coagulates physically increases curd volume. In addition, presence of starch particles in the milk gel can physically block contraction of the protein network as well as reduce attractions between proteins if the starch chemically interacts with the paracasein protein matrix. This would increase curd volume (and curd yield) and produce a gel with higher moisture content.

Severity of heat treatment influenced curd yields ( $P$ $<0.001$ ) for some of the starches (Figure 2). Under-

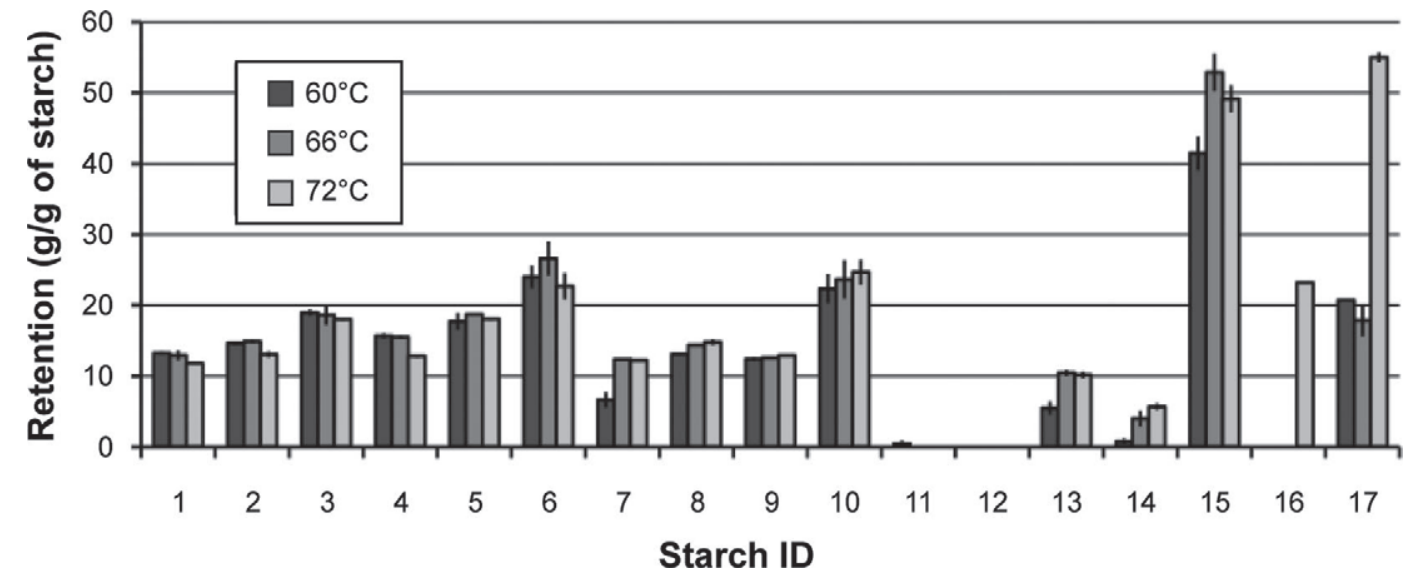

Figure 1. Water retention of starches (as described in Table 1) after centrifugation of starch solutions gelatinized at $60^{\circ} \mathrm{C}$ for 30 min, $66^{\circ} \mathrm{C}$ for $30 \mathrm{~min}$, or $72^{\circ} \mathrm{C}$. Starches 10 and 16 separated poorly during centrifugation, and water retention values were estimated or not obtainable. Error bars are SEM. 


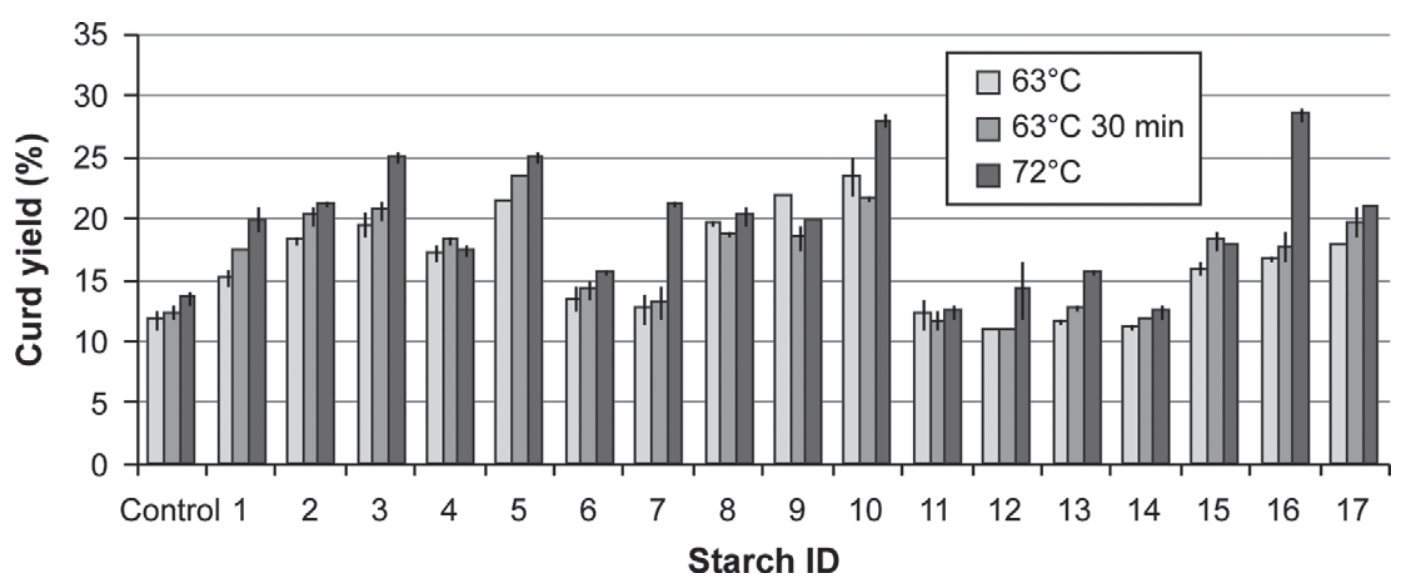

Figure 2. Curd yield from renneted acidified milk containing $5 \mathrm{~g} / \mathrm{L}$ of starches (as described in Table 1), which were heated to 63 and $72^{\circ} \mathrm{C}$, or $63^{\circ} \mathrm{C}$ and held for $30 \mathrm{~min}$ at that temperature and then centrifuged at $250 \times g$ for $30 \mathrm{~min}$ at $25^{\circ} \mathrm{C}$. Error bars are SEM.

cooking and overcooking can result in less than maximum swelling of the starch granules and some starch sedimentation occurred in milk. For starches 11, 12, and 13, it was apparent that heating was insufficient for proper starch gelatinization. Starch settling during gel formation and centrifugation was considerable for the potato starches (6 and 15), the instant waxy corn starches (4 and 5), maltodextrin (11), DX (12) with the lower heat treatment, and the instant rice starch (17). Little (if any) starch sedimentation occurred when using the waxy corn $(1,2$, and 3$)$ or the WR starches (7; when heated to $72^{\circ} \mathrm{C}$ ). Less tendency for starch settling was observed at $5 \mathrm{~g} / \mathrm{L}$ than at $10 \mathrm{~g} / \mathrm{L}$, and better curd properties and separation of whey, so $5 \mathrm{~g} / \mathrm{L}$ was used in the second trial.

Physical appearance of the centrifuged control curd for all heat treatments were similar in that the curd was very firm and rubbery with good curd and whey separation. At a starch addition level of $5 \mathrm{~g} / \mathrm{L}$, good whey separation was obtained with starches $1,2,3,7$, 8 , and 9. Poor separation occurred with starches 10 and 16. The whey released from gels containing starches appeared more viscous and slimy than the control gels, indicating less entrapment of the starches 4, 5, 10, 16, and 17 in the curd and their release into the whey. An apparent demixing and settling of the gelatinized starch from the proteins occurred in the milk gels when using tapioca starch 13 and the traditional gelling, acid-converted starch 14 . This produced curd after centrifugation that was softer at the bottom. The modified tapioca starches 10 and 16 had the most dramatic visible effect on curd properties. Both prevented the curd from settling during centrifugation, produced curds that lacked cohesion, and caused poor curd and whey separation. The whey from these samples was very slimy.

\section{Curd Yield}

In the second trial using WC, WR, IT, MT, and DX starches, no difference was observed in curd yields (or any other parameters measured) of the control milk gel after either the 72 - or $66^{\circ} \mathrm{C}$-for-30-min heat treatments (Table 2). A curd yield of $13.1 \mathrm{~g} / 100 \mathrm{~g}$ of milk was obtained. Curd yield was significantly $(P<0.05)$ increased to $18.4,20.7,21.5$, and $23.5 \mathrm{~g} / 100 \mathrm{~g}$ of milk when WC, WR, IT, and MT starches, respectively, were added to the milk. Adding DX starch did not significantly increase curd yield compared with the control.

\section{Starch Retention}

The 5 starches (WC, WR, IT, MT, and DX) when tested alone were equally recovered using the alcohol precipitation method, with recoveries calculated at 96 to $114 \%$. When supernatant whey from the centrifuged control milk was subjected to alcohol precipitation, a small amount of residue $(1.8 \mathrm{mg} / \mathrm{g})$ was present, which most likely consisted of proteins. The mean residues recovered from whey expelled from the WC, WR, IT, and DX starch-containing milk gels were 3.9, 3.2, 2.4, and $7.1 \mathrm{mg} / \mathrm{g}$, respectively. Based on the amount of whey expressed, retention of these starches in the milk gels was calculated (Table 2). The highest mean retention was for the WR and IT starches, although because of the variations inherent in this gravimetric method (e.g., recovery of precipitate and variation in whey volume) the retention of these starches was not statistically different $(P>0.05)$ from the WC starch. Very poor separation of whey from curd was observed when using MT starch, which made it difficult to calculate total starch content because of interference from milk proteins, and its retention in the curd was estimated 
Table 2. Curd and whey yields after centrifugation of $200 \mathrm{~mL}$ of acidified renneted milk containing no starch (control) or $5 \mathrm{~g} / \mathrm{L}$ of waxy corn (WC), waxy rice (WR), instant tapioca (IT), or modified tapioca (MT) starches, or dextrin (DX), along with alcohol-insoluble residue in the whey and calculated starch content of the whey and retention in the curd

\begin{tabular}{|c|c|c|c|c|c|c|}
\hline Attribute & Control & \multicolumn{5}{|c|}{ Starch type } \\
\hline Curd yield (g/100 g of milk) & $13.1^{\mathrm{a}}$ & $18.4^{\mathrm{b}}$ & $20.7^{\mathrm{c}}$ & $21.5^{\mathrm{c}}$ & $23.5^{\mathrm{d}}$ & $13.2^{\mathrm{a}}$ \\
\hline Total starch in whey ${ }^{1}(\mathrm{~g})$ & $\mathrm{NA}^{2}$ & $0.39^{\mathrm{ab}}$ & $0.26^{\mathrm{a}}$ & $0.10^{\mathrm{a}}$ & $0.79^{\mathrm{bc}}$ & $0.98^{\mathrm{c}}$ \\
\hline Starch retention in curd ${ }^{3}(\%)$ & NA & $71^{\mathrm{ab}}$ & $90^{\mathrm{a}}$ & $90^{\mathrm{a}}$ & $21^{\mathrm{bc}}$ & $1^{\mathrm{c}}$ \\
\hline
\end{tabular}

${ }^{\mathrm{a}-\mathrm{d}}$ Means within a row with the same letter are not different $(\alpha=0.05)$.

${ }^{1}$ Calculated as residue weight less residue weight from control whey as a function of their respective volumes.

${ }^{2}$ Not applicable.

${ }^{3}$ Calculated as amount added to milk less amount lost in whey.

at $20 \%$. No retention of the DX starch was observed within the milk gel.

\section{Starch Fluorescence}

Starches WC, WR, and IT, when derivatized and stained using the periodic acid-acriflavine method, fluoresced as shown for WR starch in Figure 3. The strongest fluorescence was observed around the residual starch granules, presumably because of the greater presence of oxidized glycol units that can bind the acriflavine. Both the MT and DX starches should have no granular structure, and similar particles seen using LSCM (data not shown) were probably unhydrolyzed material present in these materials. During preparation of these MT and DX starches, almost no starch pellet was recovered following staining, washing, and centrifugation.

\section{Curd Microstructure}

Control. Gels made with no starch had a microstructure that would be expected in a low-fat or non-fat system. The protein matrix dominated the curd structure, with few interruptions (Figure 4A) and the curd was visibly more compact than curd containing starch.

Waxy Corn Starch. Gels containing WC starch (Figure 4B) had more openness compared with the control, which was expected based on increased volume (yield) of curd obtained when WC starch was added. The protein network appeared less compact and swollen starch particles up to about $50 \mu \mathrm{m}$ in size were distributed throughout the matrix. The swollen starch particles were relatively large, and irregularly shaped, and the granules appear to still remain somewhat intact. The starch particles appeared to be interacting with the surface of the protein network rather than being suspended in the moisture-rich areas. An increased amount of dark space in the micrograph indicates that more moisture was incorporated into the curd. Moisture-rich areas also likely contained soluble starch, but at a level where it could not be distinguished from background staining in the images.

Waxy Rice Starch. The milk gel made with WR starch also had a more open structure consisting of a loose protein network extensively coated in small, round, discrete starch moieties (Figure 4C). Starch was located primarily at the protein-void interfaces, but some particles were visibly trapped within the protein network as well. The swollen starch granules were small and typically $<10 \mu \mathrm{m}$. From the curd structure, it is clear that a large amount of starch was retained with the curd. Large areas of continuous protein network were observed, whereas curd with WC starch (Figure 4B) had a more interrupted protein network with smaller intact protein units. Waxy rice starch particles were smaller than WC starch particles, and a considerable amount of WR starch was present in the serum

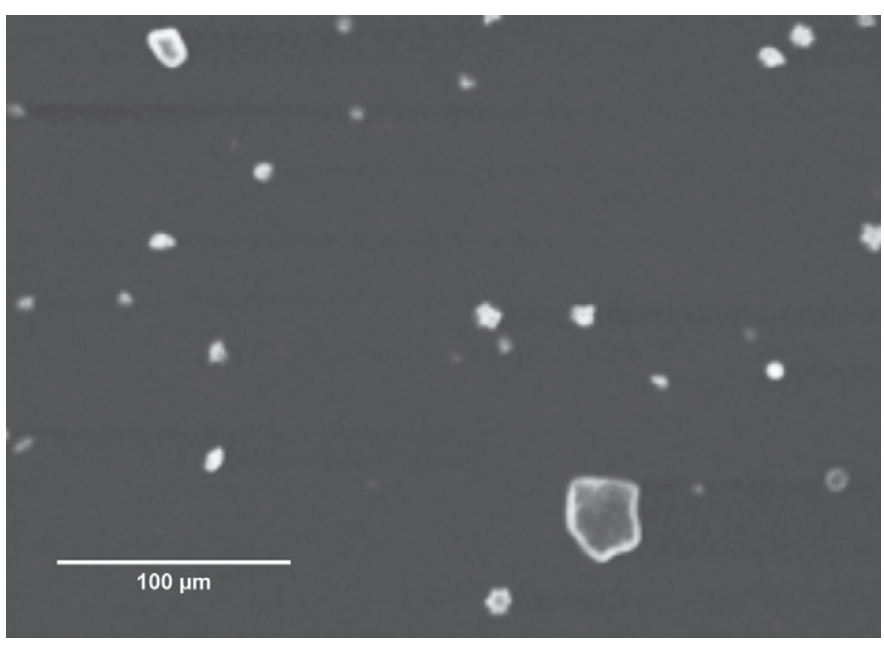

Figure 3. Laser scanning confocal micrograph of waxy rice starch as imaged using fluorescence from acriflavine. 


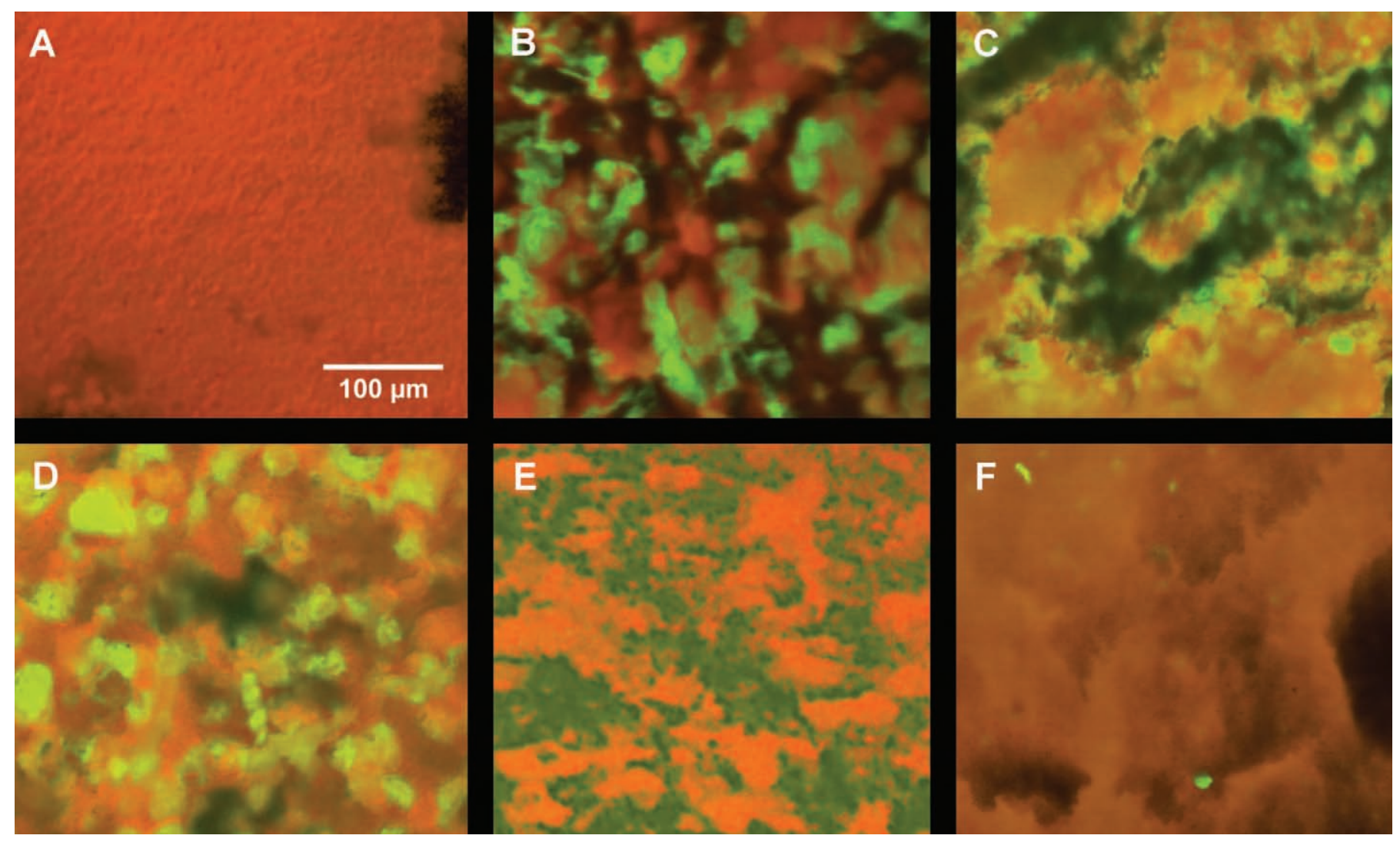

Figure 4. Laser scanning confocal micrographs of (A) control skim milk gel and skim milk gels containing (B) waxy corn starch, (C) waxy rice starch, (D) instant tapioca starch, (E) modified tapioca starch, and (F) dextrin. Red-orange represents protein, green-yellow represents starch, and dark areas represent serum voids containing whey.

voids, unlike in the WC curd where WC appeared more discrete in nature.

Instant Tapioca Starch. Inclusion of IT starch in the skim milk gels also produced a more disrupted curd structure (Figure 4D). Unlike the WC and WR starches, IT starch did not appear to be preferentially located at the protein-void interfaces. Rather, it was dispersed throughout the protein matrix and filled the spaces it created in the protein, much as fat globules in full-fat cheese do. The swollen starch particles were irregularly shaped and evenly distributed through the protein matrix.

Modified Tapioca Starch. The milk gel made with MT starch produced a curd structure with the most interruptions (Figure 4E). The protein network appeared very loose, with numerous voids, although few distinct starch structures were present. The estimated MT starch retention in the curd was only $20 \%$, and based on the lack of distinct starch regions in the curd structure this estimate seems correct. In spite of low starch retention, MT starch very effectively disrupted the protein network, creating large channels and the highest curd yield $(23.5 \mathrm{~g} / 100 \mathrm{~g}$ of milk). This is perhaps indicative of a starch gel being formed, with a phase separation occurring between the protein and the starch polymers, with both gels being compressed during centrifugation. In solution with just water, the modified food starch had a high swelling power, and the slimy, mucous-like gel that was formed did not sediment when centrifuged at $2,000 \times g$ for $20 \mathrm{~min}$. Likely, the starch interacted highly with the protein, inhibiting some of the proteinprotein interactions that occur when milk is renneted and acidified, but due to the highly soluble nature of the starch, a large portion was lost with the whey and only the portion that was physically entrapped or interacting the with protein remained in the curd.

Dextrin. Addition of DX did not increase openness of the curd (Figure 4F) and was similar to the control (Figure $4 \mathrm{~A}$ ), with its structure dominated by the protein network with few disruptions. Some small, distinct starch particles were imbedded in the protein that were likely some residual granules from preparation of the DX powder and were there only because they were physically entrapped in the curd as the curd formed 
and was compressed. Due to the low retention of DX in the curd and its inability to change the curd structure, it is likely that it did not interact with casein.

\section{DISCUSSION}

\section{Starch Imaging}

Periodic acid oxidizes glucose residues of amylose and amylopectin chains at carbons 2 and 3, splitting the bond between the 2 carbons and converting the hydroxyl groups on each to aldehydes (Lehninger, 1975; McManus et al., 2009). The presence of the dialdehyde then facilitates binding to the starch by the pseudoSchiff base acriflavine. The strongest fluorescence was observed around the residual starch granules, presumably because of the greater presence of oxidized glycol units that can bind the acriflavine. Amylose leached from granules would also bind acriflavine, but because of extensive rinsing steps during sample preparation soluble amylose molecules would be removed.

General background staining also occurred in all starch gels imaged because it is difficult to remove all excess acriflavine from the solutions. However, the amount of fluorescence was greater in areas where the fluorophore was concentrated and because acriflavine binds covalently to the derivatized starch, more fluorescence occurs in areas with more derivatized-starch aldehyde groups per unit volume. Both MT and DX starches are known to be smaller and more soluble than WC, WR, and IT starches, and the several washing steps required to properly gelatinize, oxidize, and stain the starches may have removed much of the starch from the solutions. When staining starch within skim milk gels, fewer washing steps are involved and the starch remains entrapped in the protein network, so washing away soluble starch materials present in the protein gel is not as much of a concern.

The curd samples used for LSCM imaging were initially stored in an osmium tetroxide in whey solution to fix protein and make the sample firmer and, therefore, easier to prepare for LSCM imaging. Previous attempts to analyze unfixed curd were unsuccessful, as the curd was too soft to be thinly sliced and fell apart during washing and staining. Osmium was selected as the fixative of choice because of its ability to crosslink proteins without changing the microstructure of the material (Bourne and Danielli, 1967). Also, unlike glutaraldehyde, it did not add free aldehyde groups to the sample, which was important because of the starch-staining technique. Controlled microwaving of the samples during fixing, staining, and washing steps was done to hasten penetration of the fixative, stain, and other items (Horobin and Flemming, 1990).
Because acriflavine fluoresces without being bound to starch, a general background fluorescence from acriflavine was expected; however, most excess acriflavine can be rinsed from the milk gels. With concentration of the fluorophore in starch-rich areas, the difference in level of fluorescence allowed starch identification in the curd. Because skim milk was used to make the gel, the amount of fat present in the curd was minimal and was not imaged, as no fat stain was present that fluoresced at different wavelengths than acriflavine and rhodamine B.

\section{Starch in Curd}

The 5 starches used in the second trial were selected to represent the different performances in renneted milk observed in the initial study. Waxy corn starch 1 was selected to represent starches 1,2 , and 3 , which all had similar properties. Dextrin (starch 12) was selected to represent starches with little apparent effect on curd formation and syneresis. Modified tapioca starch 10 was selected because it greatly increased the curd volume and changed the curd appearance. Instant tapioca (IT) starch 9 was selected as an example of a starch that had undergone gelatinization and drying steps during its manufacture. Waxy rice starch 7 was selected because it had a different botanical source from the other starches and had a much smaller granule size.

Waxy corn starch has high amylopectin content, and because it is crosslinked and modified, it is more resistant to degradation than its native counterpart. At $72^{\circ} \mathrm{C}$, WC had a high swelling power relative to lower temperatures, but likely swelled more if given a more severe heat treatment. Because it is more resistant, some granules are likely still intact within the curd matrix. In imitation low-fat cheese made with resistant corn starch, the starch was shown to be granular still and dispersed homogenously throughout the matrix, rather than forming swollen clusters (Noronha et al., 2008). Curd yield was close to $19 \%$, evidence of WC's high affinity for water combined with prevention of curd shrinkage during centrifugation

Waxy rice starch was retained well in the curd and also increased yield more than other starches with the $72^{\circ} \mathrm{C}$ heat treatment. This starch has very small granules, high water-binding capacity, and high amylopectin content. Because the unswollen granules only range from 3 to $8 \mu \mathrm{m}$, they can impart a creamy mouthfeel to products in which they are used. Rice starches have often been used as a fat mimetic. In the skim milk gel with WR starch good retention in the curd was observed, and also a high yield. The curd was soft and voluminous, similar to the curd made with the WC starch. In a study of acidified skim milk containing rice 
starch (Zuo et al., 2008), it was found that rice starch acts as an inactive filler and absorbs water from the continuous phase, thereby concentrating the protein, a trait likely more desirable in acidified milk products such as yogurt, where whey expulsion is undesirable, but in products such as low-fat cheese, further protein concentration is unwanted. If the heat treatment given to the milk and starch before cheese making is sufficient to cause maximal granule swelling before renneting and acidification of the milk, it may be possible to inhibit further water uptake by the starch from the protein.

Instant tapioca starch had very good retention in the curd. This curd was soft but cohesive, and had good curd and whey separation. Low- and reduced-fat Feta cheese with tapioca starch has been studied (Sipahioglu et al., 1999), and it increased the moisture content and hardness of cheese, but did not significantly improve texture, flavor, or overall acceptability over low-fat controls. However, in that study, milk did not receive an appreciable heat treatment once starch was added, suggesting that the starch was more likely to absorb water from the protein during storage, and it may have given a grainy feel to the cheese. In our study, IT starch was used, which requires very little heat for dispersion and swelling to occur.

Modified tapioca starches are typically used to change mouthfeel in dairy products. In the skim milk gels, it made the curd very soft, and not as cohesive as curds made with the other starches. Boundaries where the curd was cut did not meld back together well, as they did in other curds. The whey decanted from this curd was thicker and slimier than control whey, indicating starch loss in the whey. This was confirmed by the whey analysis test, which showed only $21 \%$ retention in the curd. Interestingly, this curd also had the highest yield, perhaps indicative of the high hygroscopicity of this starch. The MT starch apparently disrupts protein interactions that normally occur in renneted acidified milk, thus restricting curd shrinkage and syneresis. This trait was even more apparent in curds made with $10 \mathrm{~g}$ of starch/L of milk (data not shown), where separation of curd and whey was almost impossible. However, at $5 \mathrm{~g} / \mathrm{L}$, this starch could likely impart the desired discontinuity to low-fat cheese by interfering with hydrophobic interactions that foster contraction of the curd protein matrix.

All curds made with starch had higher yields than controls, except for the DX starch-containing curd. This was expected because in tests measuring starch swelling under the heat treatments used, DX had very low swelling power (data not shown). It also had the lowest retention in curd, probably because it is made up of smaller molecules that are more soluble and less likely to get trapped within the curd. The curd made with DX starch had an appearance and feel similar to the control gel, which was firm and rubbery.

\section{CONCLUSIONS}

Low-fat cheese curd normally has a dense protein network. Addition of WC starch produced a loose protein network with irregularly shaped starch granules evenly distributed around and throughout that matrix; retention of WC in the curd was $71 \%$. The WR starch was $90 \%$ retained and produced a curd that was also dense, with small granules of starch coating the protein strands rather than being distributed throughout the curd. A 90\% retention in curd was also obtained with IT starch and it similarly coated protein strands but was not in granular form. The MT starch interacted highly with the protein, as the curd network was very loose. The starch seemed to be in solution around, as well as incorporated into the protein, but was only $12 \%$ retained in the curd. Virtually no retention of DX in the curd was observed. All starches except DX increased the curd yield with the effect being MT > $\mathrm{IT}=\mathrm{WR}>\mathrm{WC}>\mathrm{DX}=$ control. The WC, WR, and IT starches have potential for improving the texture of low-fat cheese because they are retained well in the protein network during coagulation and produce interruptions in the curd network that may help limit extensive protein-protein interactions.

\section{ACKNOWLEDGMENTS}

Financial support for this research was provided by Dairy Management Inc. (Rosemont, IL) as administered by the Dairy Research Institute. We thank National Starch LLC (Bridgewater, NJ) for donation of the starches and technical advice. This research was supported by the Utah Agricultural Experiment Station and Utah State University (Logan).

\section{REFERENCES}

AOAC (Association of Official Analytical Chemists). 1990. Official Methods of Analysis. 15th ed. Method 985.29. AOAC, Gaithersburg, MD.

Aryana, K. J., and Z. U. Haque. 2001. Effect of commercial fat replacers on the microstructure of low-fat Cheddar cheese. Int. J. Food Sci. Technol. 36:169-177.

BeMiller, J. N., and R. L. Whistler. 1996. Carbohydrates. Pages $157-$ 223 in Food Chemistry. O. R. Fennema, ed. Marcel Dekker Inc., New York, NY.

Bhaskaracharya, R. K., and N. P. Shah. 2001. Texture and microstructure of skim milk Mozzarella cheeses made using fat replacers. Aust. J. Dairy Technol. 56:9-14.

Bourne, G. H., and J. F. Danielli. 1967. International Review of Cytology, Volume 22. Academic Press, Inc., New York, NY.

Cody, T. L., A. Olabi, A. G. Pettingell, P. S. Tong, and J. H. Walker. 2007. Evaluation of rice flour for use in vanilla ice cream. J. Dairy Sci. 90:4575-4585. 
Drake, M. A., W. Herrett, T. D. Boylston, and B. G. Swanson. 1996. Lecithin improves texture of reduced-fat cheese. J. Food Sci. 61:639-642.

Drake, M. A., and B. G. Swanson. 1995. Reduced-fat and low-fat cheese technology - A review. Trends Food Sci. Technol. 6:366-369.

FDA (Food and Drug Administration). 2012. Requirements for foods named by use of a nutrient content claim and a standardized term. Code of Federal Regulations, Title 21, Part 130.10. FDA, Department of Health and Human Services, Washington, DC.

Horobin, R. W., and L. Flemming. 1990. 'Trouble-shooting' microwave accelerated procedures in histology and histochemistry: Understanding and dealing with artefacts, errors and hazards. Histochem. J. 22:371-376.

Horobin, R. W., and J. A. Kiernan. 2002. Conn's Biological Stains. 10th ed. BIOS Scientific Publishers Ltd., Oxford, UK.

Johnson, M. E., R. Kapoor, D. J. McMahon, D. R. McCoy, and R. G. Narasimmon. 2009. Reduction of sodium and fat levels in natural and processed cheeses: Scientific and technological aspects. Comprehensive Rev. Food Sci. Food Safety 8:252-268.

Kavas, G., G. Oysun, O. Kinik, and H. Uysal. 2004. Effect of some fat replacers on chemical, physical, and sensory attributes of low-fat white pickled cheese. Food Chem. 88:381-388.

Konik-Rose, C. M., R. Moss, S. Rahman, R. Appels, F. Stoddard, and G. McMaster. 2001. Evaluation of the $40 \mathrm{mg}$ swelling test for measuring starch functionality. Starch 53:14-20.

Konuklar, G., G. E. Inglett, C. J. Carriere, and F. C. Felker. 2004 Use of a $\beta$-glucan hydrocolloidal suspension in the manufacture of low-fat Cheddar cheese: Manufacture, composition, yield and microstructure. Int. J. Food Sci. Technol. 39:109-119.

Lehninger, A. L. 1975. Biochemistry: The Molecular Basis of Cell Structure and Function. 2nd ed. Worth Publishers Inc., New York, NY.

Liu, H., X. M. Xu, and S. D. Guo. 2008. Comparison of full-fat and low-fat cheese analogues with or without pectin gel through microstructure, texture, rheology, thermal and sensory analysis. Int. J. Food Sci. Technol. 43:1581-1592.

Lobato-Calleros, C., A. Sosa-Pérez, J. Rodríguez-Tafoya, O. SandovalCastilla, C. Pérez-Alonso, and E. J. Vernon-Carter. 2008. Structural and textural characteristics of reduced-fat cheese-like products made from $\mathrm{W}_{1} / \mathrm{O} / \mathrm{W}_{2}$ emulsions and skim milk. Lebensm. Wiss. Technol. 41:1847-1856.

McMahon, D. J., M. C. Alleyne, R. L. Fife, and C. J. Oberg. 1996. Use of fat replacers in low fat Mozzarella cheese. J. Dairy Sci. 79:1911-1921.

McManus, W. R., K. M. Larsen, and D. J. McMahon. 2009. Identification of starch in milk protein gels using confocal microscopy. Microscopy Today 17:68-69.
Merrill, R. K., and T. L. Anderson, inventors. 2007. Process of making a homogeneous cheese. Leprino Foods Co., assignee. US Patent No. $7,169,429$ B2.

Mistry, V. V. 2001. Low-fat cheese technology. Int. Dairy J. 11:413422

Noronha, N., E. Duggan, G. R. Ziegler, E. D. O'Riordan, and M. O. Sullivan. 2008. Inclusion of starch in imitation cheese: Its influence on water mobility and cheese functionality. Food Hydrocoll. $22: 1612-1621$.

Paulson, B. M., D. J. McMahon, and C. J. Oberg. 1998. Influence of sodium chloride on appearance, functionality, and protein arrangements in nonfat Mozzarella cheese. J. Dairy Sci. 81:2053-2064.

Perry, D. B., D. J. McMahon, and C. J. Oberg. 1997. Effect of exopolysaccharide-producing cultures on moisture retention in low-fat Mozzarella cheese. J. Dairy Sci. 80:799-805.

Rahimi, J., A. Khosrowshahi, A. Madadlou, and S. Aziznia. 2007. Texture of low-fat Iranian white cheese as influenced by gum tragacanth as a fat replacer. J. Dairy Sci. 90:4058-4070.

Rogers, N. R., D. J. McMahon, C. R. Daubert, T. K. Berry, and E. A. Foegeding. 2010. Rheological properties and microstructure of Cheddar cheese made with different fat contents. J. Dairy Sci. 93:4565-4576.

Sandoval-Castilla, O., C. Lobato-Calleros, E. Aguirre-Mandujano, and E. J. Vernon-Carter. 2004. Microstructure and texture of yogurt as influenced by fat replacers. Int. Dairy J. 14:151-159.

Sipahioglu, O., V. B. Alvarez, and C. Solano-Lopez. 1999. Structure, physico-chemical and sensory properties of feta cheese made with tapioca starch and lecithin as fat mimetics. Int. Dairy J. 9:783789.

Stanley, D. W., H. D. Goff, and A. K. Smith. 1996. Texture-structure relationships in foamed dairy emulsions. Food Res. Int. 29:1-13.

Totosaus, A., and N. Guemes-Vera. 2008. Effect of $\kappa-$ and $\lambda$-carrageenans as fat-replacers in low-fat Oaxaca cheese. Int. J. Food Properties 11:656-668.

Trivedi, D., R. J. Bennett, Y. Hemar, D. C. W. Reid, S. K. Lee, and D. Illingworth. 2008. Effect of different starches on rheological and microstructural properties of (II) commercial processed cheese. Int. J. Food Sci. Technol. 43:2197-2203.

Vithanage, C. J., V. K. Mishra, T. Vasiljevic, and N. P. Shah. 2008. Use of $\beta$-glucan in development of low-fat Mozzarella cheese. Milchwissenschaft 63:420-423.

Zuo, J. Y., Y. Hemar, S. Hewitt, and A. Saunders. 2008. Effect of the extent of pasting on the dynamic rheological properties of acidified skim milk gels containing normal rice starch. Food Hydrocoll. $22: 1567-1573$. 